\title{
POLLINATORS ACTIVITY ON ONION FLOWERS AND ITS EFFECT ON SEEDS YIELD AT SOHAG GOVERNORATE, EGYPT
}

\author{
MAZEED, A. R. ${ }^{1}$ and R. A. MAREY ${ }^{2}$ \\ 1. Beekeeping Research Dept. Plant Protection Institute, A.R.C. \\ 2. Onions Research Dept. Field Crops Research Institute, A.R.C.
}

(Manuscript received 15 October 2017)

\begin{abstract}
$\mathrm{T}$ he present investigations were carried out at Shandaweel Agricultural Research Station, Sohag Governorate, Egypt during 2015/2016 and 2016/2017 seasons to survey onion pollinators, study the population dynamic of the dominant pollinators during the flowering season and their diurnal activity. Also, to make a comparison between seed yield of caged and uncaged (open-pollinated) plants. Data revealed that onion flowers were visited by 21 species of insects belong to 14 families and 7 orders. Of all species 16 species were identified and 5 were not identified 2 species belong to Sarcophaga genus and 3 belong to Syrphus genus. Order Diptera was most abundant $30 \%$ followed by Hymenoptera $21 \%$, Lepidoptera, Coleoptera $14 \%$, and $7 \%$ for Hemiptera, Neuroptera and Thysanoptera. Of all the insect visitors, Apis mellifera L., Musca domestica (Macq.), Lucilia illustris Meigen and Syrphus spp. were the most abundant visitors. The pollinators were detected during the last week of March till the last week of April. The populations of $A$. mellifera and $M$. domestica gave the highest and significant values followed by L. illustris and Syrphus spp. The activity of these pollinators increased gradually at morning and reaches its peak at 12:00 h., with averages of 4.58, $4.39,4.00$ and 2.21 pollinators/ 25 plants / $/ \mathrm{min}$. / plant, respectively in the first, and $3.52,4.18,3.09$ and 2.33 pollinators/25 plants /min. / plant, respectively in the second season. Also, the yield of seeds from plants covered and isolated from insects decreased significantly with an averages of (45.40 and 47.60 seeds/ 20 umbels), whereas open-pollinated plants produced (711.60 and 721.10 seeds/ 20 umbels) at 2015/2016 and 2016/2017 seasons respectively.
\end{abstract}

Keywords: Onion, Pollinators, Activity, Free pollination, Seed yield.

\section{INTRODUCTION}

Onion (Allium cepa L.) is an import vegetable crop worldwide and has been used in various forms of food as salads, as a raw or cooked vegetable and as a condiment. A global review of major vegetables shows that onion ranks second after tomato in area. Approximately, 36 million tonnes of onion are produced on 2-5 million ha globally (Devi et al., 2015)

Onion flowers are protandrous and pollen is shed within 2-3 days before the stigma is receptive (Lesley and Ockendon, 1978), single umbel flowers of the onion inflorescence are not capable of self-pollinating. In order for its pollination to occur, 
the pollen must come from another flower of the same or different plant therefore, self-pollination within a flower is not possible (Wilkaniec et al., 2004). Thus, crosspollination is common in onion (Chandel et al., 2004). Insect pollination is necessary for many cross pollinated crops especially in the case of hybrid seed production e.g. onion (Mayer and Lunden, 2001). The absence of natural pollinators on onion seed plantations poses a serious problem for breeders all over the world (Wilkaniec et al., 2004). Nearly $75 \%$ of the world's flowering plants are dependent on insects for pollination, (Bezabih and Gebretsadikan, 2014). Although many arthropod species visit A. cepa flowers, for most there is little information on their role as pollinators (Walker et al., 2011).

The objective of this study was to survey onions pollinators, study the population dynamic of the dominant pollinators during the flowering season and their diurnal activity. Also, make a comparison between seed yield of caged and uncaged (open-pollinated) plants.

\section{MATERIALS AND METHODS}

The present studies were carried out at the Experimental Farm of Shandaweel Agricultural Research Station at Sohag Governorate, during two successive growing seasons of 2015/2016 and 2016/2017. An area of about 1/8 of feddan was assigned for different experiments conducted in the current study. By the mid of November in the two seasons, the onions bulb were planted with three replicates in complete randomized blocks design. Experimental plots received regular cultural practices as recommended, except the use of any pesticides.

Direct observations and sweep net collection methods were used to survey certain insects that visited and occurred on onion umbels. Unknown collected adults were identified at the Plant Protection Institute, Agriculture Research Centre in Giza, Egypt.

Pollinators abundance and population dynamics were calculated by randomly observing 25 plants /min. /plant and counting the number of individuals visits for each of the different pollinator species. Observations were made in two-hourly intervals from 8:00 AM to 4:00 PM throughout the day and repeated twice a week during the full flowering period. For comparison of caged plants and open-pollinated plants for 20 umbels of same age were veiled with nylon mesh bags before opening of the flowers and another 20 umbels were tagged for open pollination, respectively (Sajjad et al., 2008). 
For statistical analysis data were analyzed by analysis of variance. When the resulted $(F)$ was significant, Duncan's multiple range test was used to partition the means into significant ranges (Snedecor, 1956).

\section{RESULTS AND DISCUSSION}

As shown in table (1). data give a general picture for the insect specimens that have been identified. However, insects listed in table (1) represent 21 species of insects belong to 14 families and 7 orders. Of all species 16 species were identified and 5 were not identified 2 species belong to Sarcophaga genus and 3 belong to Syrphus genus. Order Diptera was most abundant $30 \%$ followed by Hymenoptera $21 \%$, Lepidoptera, Coleoptera $14 \%$ and $7 \%$ for Hemiptera, Neuroptera and Thysanoptera (Fig, 1).

Honey bees( Apis mellifera L.) were recorded as important pollinators on onion umbels as pollen and nectar gatherers. Of all the insect visitors, A. mellifera, Musca domestica, Lucilia illustris and Syrphus spp. were the most Abundant visitor.

Table 1. A partial taxonomic list of insects collected from onion umbels by using sweep net and direct count methods during (2015/2016 and 2016/2017) seasons.

\begin{tabular}{|c|c|c|c|c|}
\hline Order & Family & Common name & Scientific name & $\begin{array}{c}\text { Frequenc } \\
y \\
\end{array}$ \\
\hline \multirow{6}{*}{ Hymenoptera } & \multirow{2}{*}{ Apidae } & Honey bees & Apis mellifera L. & Abundant \\
\hline & & Carpenter bee & Xylocopa pubescens Spinola & Rare \\
\hline & Sphecidae & The bee-wolf & Philanthus triangulum $\mathrm{F}$. & Rare \\
\hline & \multirow{3}{*}{ Vespidae } & Oriental hornet & Vespa orientalis L. & Rare \\
\hline & & Paper wasp & Polistes gallicus L. & Rare \\
\hline & & Yellow jacket & Vespula squamosa D. & Rare \\
\hline \multirow{2}{*}{ Lepidoptera } & Pieridae & Small cabbage white & Pieris rapae $\mathrm{L}$. & Rare \\
\hline & Lycaenidae & The pea blue butterfly & Lampides boeticus $\mathrm{L}$. & Rare \\
\hline \multirow{5}{*}{ Diptera } & Muscidae & Orientalis house fly & Musca domestica (Macq.) & Abundant \\
\hline & Sarcophagidae & True flies & Sarcophaga spp. & Frequent \\
\hline & \multirow{2}{*}{ Calliphoridae } & Green bottle fly & Lucilia illustris (Meigen) & Abundant \\
\hline & & Blue bottle fly & Calliphora vomitoria $\mathrm{L}$. & Frequent \\
\hline & Syrphidae & Hover or flower fly & Syrphus spp. & Abundant \\
\hline \multirow{2}{*}{ Coleoptera } & Coccinellidae & The lady beetle & Coccinella undecimpunctata $\mathrm{L}$. & Frequent \\
\hline & Scarabaeidae & The peach cockchafer & Pachnoda fasciata $\mathrm{F}$. & Rare \\
\hline Neuroptera & Chrysopidae & The green lacewing & Chrysoperla carnea ( Steph.) & Rare \\
\hline Hemiptera & Anthocoridae & (Flower) Orius bugs & Orius sp. & Frequent \\
\hline Thysanoptera & Thripidae & Onion thrips & Thrips tabaci Lind. & Abundant \\
\hline
\end{tabular}

Abundant: Insect visits the flower every day during the onion flowering season.

Frequent: Insect visits the flower a lot but not every day during the onion flowering season.

Rare: Insect visits the flower once or twice/ 25 plants / $\mathrm{min}$. /plant during the onion flowering season. 


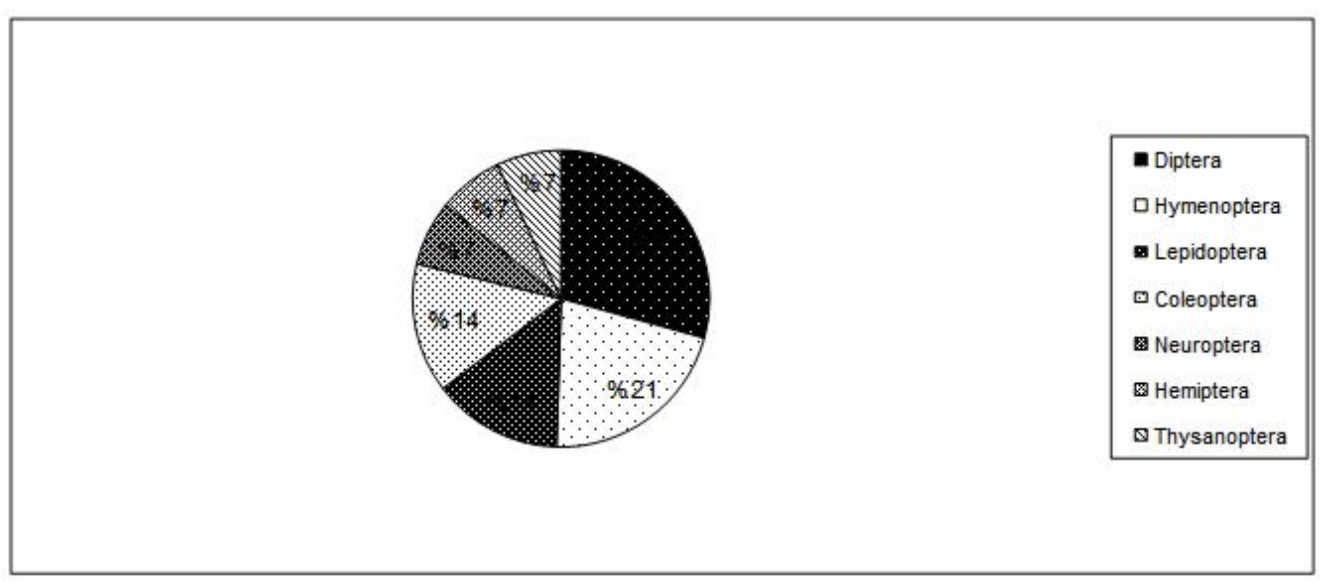

Fig. 1. Percentage of different insect orders visit onions umbels during 2015/2016 and 2016/2017.

Generally, pollinating insects vary from region to region. These data were in partial agreement with those of Walker et al. (2011) in New Zealand who found that insects belonging to the orders Thysanoptera and Diptera were the most abundant and Hymenoptera, Hemiptera, Coleoptera, Collembola, and Psocoptera were also present. Sajjad et al. (2008) Also, surveyed onions pollinators and observed that the spectrum of pollinators abundance was composed $87 \%$ of dipteran species and remaining $13 \%$ of Hymenoptera species.

Saeed et al. (2008). Stated that the community of pollinators was composed of four bee species and twelve true fly species whereas, Kalmath and Sattigi (2005) recorded four groups of pollinators in India in the onions ecosystem. Of these, Hymenoptera $(90.15 \%)$ was the dominant group followed by Diptera $(6.63 \%)$, Lepidoptera (1.70\%) and other insects (1.52\%).

El-Zakardy et al. (1999) in Egypt, found that insects belonging to five orders i.e. Hymenoptera, Diptera, Lepidoptera, Coleoptera and Neuroptera visited onions umbels.

\section{Population dynamic of the dominant insects visits onion flowers during the onions flowering two seasons.}

Data graphically illustrated in Fig. (2 and 3) show the population densities of A. mellifera, M. domestica, L. illustris and Syrphus spp. during the two successive onion growing seasons, 2015/2016 and 2016/2017.

In the first season 2015/2016 in fig. (2), the insects were detected during the last week of March. Then the population dynamic began to increase gradually to reach its peak (44.67, 44.67, 24.67 and 32.67 adults / 25 plants /min. / plant) respectively on the $3^{\text {rd }}$ of April and then decreased gradually to the end of the flowering season. 
In the second season 2016/2017 in fig. (3), the insects were detected during the Last week of March and then the population dynamic began to increase gradually to reach its peak (32.33, 30.00, 15.33 and 25.67 adults / 25 plants / min. / plant) respectively on the first week of April and then decreased gradually to the end of the flowering season.

According to Saeed et al. (2008). The maximum pollinator activity was observed from 12 to 24 days after opening of the flowers.

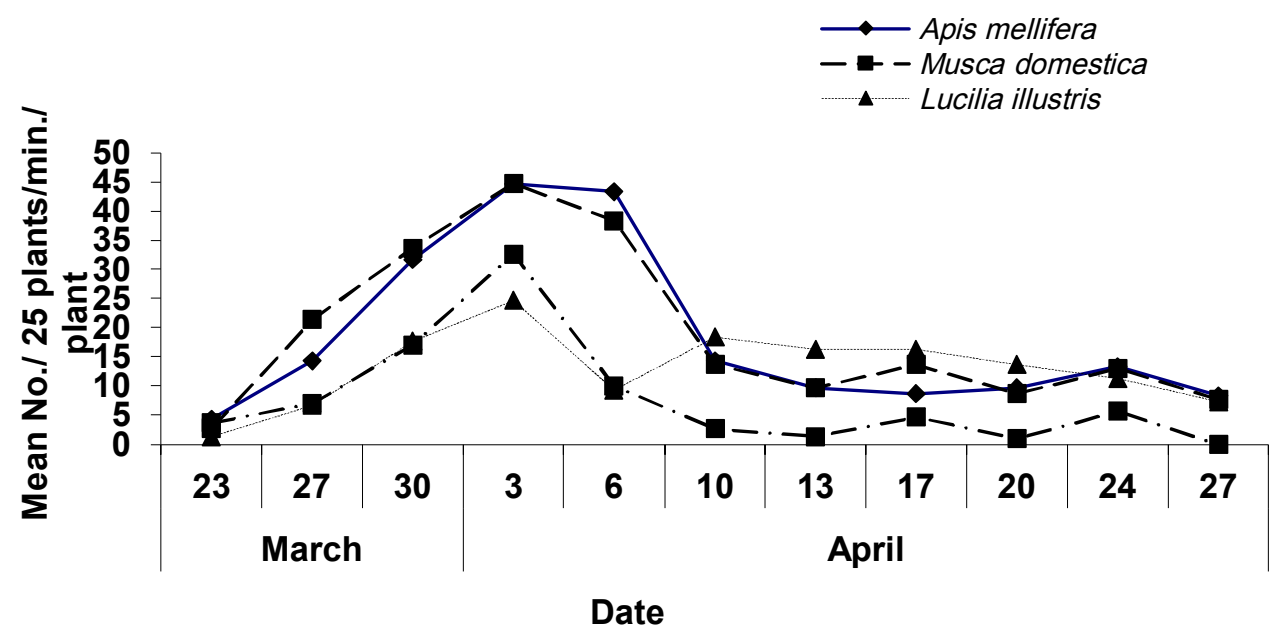

Fig. 2. Population dynamic of the dominant insects visit onions flowers during the onions flowering season of 2015/2016.

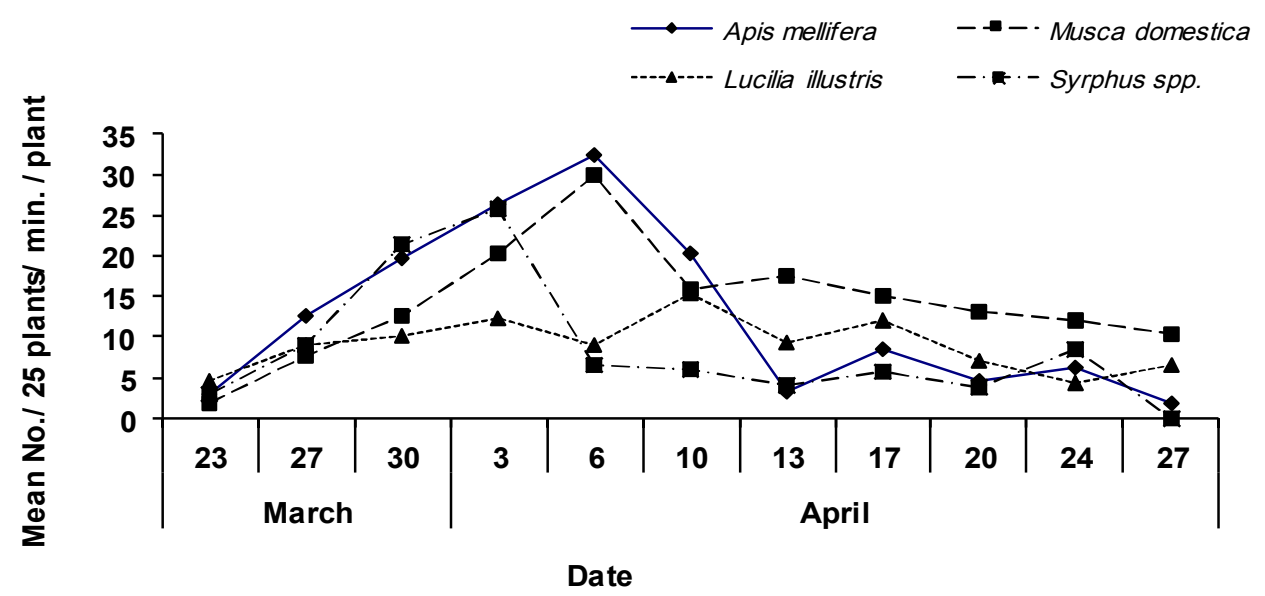

Fig. 3. Population dynamic of the dominant insects visit onions flowers during the onions flowering season of $2016 / 2017$. 
The mean numbers of the dominant insect pollinators were presented in Table (2). During the first season, $M$. domestica was found to be the most abundant pollinator on onion flowers (18.82 individuals / 25 plants / min. / plant) with insignificant difference with $A$. mellifera (18.39 individuals / 25 plants / min. / plant). However, Syrphus spp. recorded the lowest mean number (7.79 individuals / 25 plants / min. / plant).

Table 2. Mean numbers of the dominant pollinators / 25 plants / min. / plant visits onions umbels during 2015/2016 and 2016/2017 seasons.

\begin{tabular}{|l|c|c|c|c|}
\hline \multirow{2}{*}{ Pollinators } & \multicolumn{2}{|c|}{$\begin{array}{c}\text { Mean No. of pollinators/ 25 } \\
\text { plants for 60 seconds/ plant }\end{array}$} & \multicolumn{2}{c|}{ Percentage \% } \\
\cline { 2 - 5 } & $\begin{array}{c}\mathbf{2 0 1 5 / 2 0 1 6} \\
\text { season }\end{array}$ & $\begin{array}{c}\mathbf{2 0 1 6 / 2 0 1 7} \\
\text { season }\end{array}$ & $\begin{array}{c}\mathbf{2 0 1 5 / 2 0 1 6} \\
\text { season }\end{array}$ & $\begin{array}{c}\mathbf{2 0 1 6 / 2 0 1 7} \\
\text { season }\end{array}$ \\
\hline Apis mellifera & 18.39 A & 31.71 B & 12.64 & 25.55 \\
\hline Musca domestica & 18.82 A & 32.45 A & 17.73 & 35.85 \\
\hline Lucilia illustris & 13.00 B & 22.41 C & 10.61 & 21.45 \\
\hline Syrphus spp. & 7.79 C & 13.43 D & 8.48 & 17.16 \\
\hline Total & $\mathbf{5 8 . 0 0}$ & $\mathbf{1 0 0 . 0 0}$ & $\mathbf{4 9 . 4 5}$ & $\mathbf{1 0 0 . 0 0}$ \\
\hline F. value & $\mathbf{1 4 . 1 5 * *}$ & $\mathbf{5 6 . 3 0 * *}$ & ---- & ---- \\
\hline
\end{tabular}

Means followed by the same letter are not significantly different at 0.05 level of probability.

Also, in the second season, M. domestica and Syrphus spp. was the most and lowest abundant, (32.45 and 13.43 individuals / 25 plants / min. / plant) respectively. These results are in agreement with Saeed et al. (2008), who found that Episyrphus balteatus De Geer, Eupeodes sp., Musca domestica and Eristalinus aeneus Scopoli were the most abundant pollinators.

Chandel et al. (2004) stated that in various regions of India, the most effective onion pollinators were Apis dorsata Fabricius, followed by $A$. cerana Fabricius, A. florea Fabricius and A. mellifera Linnaeus. Also Syrphidae family, order Diptera takes part in the process of pollination. Onions umbels are visited by honey bees, small syrphid flies, bumble bees, halictid bees, drone flies, butterflies and insects of minor importance with respect to pollination (Sajjad et al., 2008). Witter and Blochtein (2003) reported that $A$. mellifera transported more than 70 percent of pollen and become indispensable in onion pollination.

\section{Diurnal abundance dynamics of onions dominant pollinators:}

During all seasons Table (3) revealed that pollinators, A. mellifera, $M$. domestica, L. illustris and Syrphus spp. activity increase gradually at morning and peaked at 12:00 PM. Comparing the data in table (3), it is clear that the highest activity period for $A$. mellifera was detected at 12:00 PM. followed insignificantly by 
Table 3. Abundance of the dominant pollinators on A. cepa umbels at different hours of the day during $2015 / 2016$ and $2016 / 2017$ seasons.

\begin{tabular}{|c|c|c|c|c|c|c|c|c|}
\hline \multicolumn{9}{|c|}{ Mean No. of pollinators/ 25 plants for 60 seconds/ plant } \\
\hline \multirow[b]{2}{*}{ Hours } & \multicolumn{2}{|c|}{ A. mellifera } & \multicolumn{2}{|c|}{ M. domestica } & \multicolumn{2}{|c|}{ L. illustris } & \multicolumn{2}{|c|}{ Syrphus spp. } \\
\hline & $\begin{array}{c}2015 / \\
2016 \\
\text { season }\end{array}$ & $\begin{array}{c}2016 / \\
2017 \\
\text { season } \\
\end{array}$ & $\begin{array}{c}2015 / \\
2016 \\
\text { season }\end{array}$ & $\begin{array}{c}2016 / \\
2017 \\
\text { season }\end{array}$ & $\begin{array}{c}2015 / \\
2016 \\
\text { season }\end{array}$ & $\begin{array}{c}2016 / \\
2017 \\
\text { season }\end{array}$ & $\begin{array}{c}2015 / \\
2016 \\
\text { season }\end{array}$ & $\begin{array}{c}2016 / \\
2017 \\
\text { season }\end{array}$ \\
\hline 8:00 AM. & $2.91 \mathbf{B}$ & $2.03 \mathrm{C}$ & 3.24 B & $3.09 \mathrm{~A}$ & $1.33 \mathrm{D}$ & $1.52 \mathrm{C}$ & $1.09 \mathrm{C}$ & $1.18 \mathrm{C}$ \\
\hline 10:00 AM. & $3.97 \mathrm{~A}$ & $2.33 \mathrm{BC}$ & $3.39 \mathbf{A B}$ & $3.18 \mathbf{A}$ & $2.18 \mathrm{C}$ & $1.64 \mathrm{C}$ & $1.48 \mathrm{BC}$ & 1.79 B \\
\hline 12:00 PM. & $4.58 \mathrm{~A}$ & $3.52 \mathrm{~A}$ & $4.39 \mathrm{~A}$ & $4.18 \mathrm{~A}$ & $4.00 \mathrm{~A}$ & $3.09 \mathrm{~A}$ & $2.21 \mathbf{A}$ & $2.33 \mathbf{A}$ \\
\hline 2:00 PM. & 2.91 B & $1.94 \mathrm{C}$ & $3.76 \mathbf{A B}$ & $3.48 \mathrm{~A}$ & $2.61 \mathrm{BC}$ & $1.67 \mathrm{C}$ & $1.18 \mathrm{C}$ & $1.27 \mathrm{C}$ \\
\hline 4:00 PM. & $4.03 \mathrm{~A}$ & 2.82 B & $4.03 \mathbf{A B}$ & 3.79 A & $2.88 \mathrm{~B}$ & $2.70 \mathrm{~B}$ & $1.82 \mathrm{AB}$ & $1.91 \mathbf{A B}$ \\
\hline F. value & $6.11 *$ & $11.68 * *$ & 2.12 & 1.90 & $51.86 * *$ & $\begin{array}{c}179.19 * \\
*\end{array}$ & $6.17^{*}$ & $9.88 * *$ \\
\hline
\end{tabular}

Means followed by different letters are significantly different (Duncan Test at $0.05 \%$ )

10:00 AM and 4:00 PM. However, the lower activity was found at 8:00 AM. and 2:00 PM. in the first season.

Also, in the second season the highest activity was found at 12:00 PM., while the lower one was at 2:00 PM. with insignificant difference between the last one and 8:00 AM. and 10:00 AM..

The highest and the lowest activity periods of $M$. domestica were observed at 12:00 PM and 8:00 AM., respectively with insignificant differences between the highest and the lowest in 2015/2016 season, however no significant difference were found between the tested day hours in 2016/2017 season.

For $L$. illustris, the highest and the lowest diurnal activity were found during 12:00 PM. and 8:00 AM., respectively in both seasons, by insignificant differences between the last one and 10:00 AM. and 2:00 PM in the second season.

Syrphus spp. recorded the highest number during 12:00 PM. with followed insignificantly by 4:00 PM in both seasons. On the other hand, 8:00 AM observation recorded the lowest mean number with insignificant differences with 10:00 AM. and 2:00 PM. in 2015/2016 season and with 2:00 PM. in 2016/2017 season.

As the temperature rose at 2:00 PM., a sharp decline in activity was observed, which again started increasing at 4:00 PM. 
According to Mupade et al. (2009) Honey bees started visiting the onion crop at 8.00 AM., population was high during 1.00-4.00 PM., declined slowly during 4.006.00 PM.. Sajjad et al. (2008). Found that $A$. dorsata and $A$. florea activity started early in the morning i.e. 6:00 AM., then their activity increased, peaking between 10:00 AM. and 12:00 AM., whereas at 2:00 PM., a sharp decline in activity was observed, which again started increasing at 4:00 PM. , then decreased again to minimum up to 6:00 PM. (sunset). Kalmath and Sattigi (2005). Reported that the activity of pollinator fauna was more during 10.00 AM.-12.00 PM. Partap and Verma (1994), Priti, (1998) and Chandel et al. (2004) founds that the foraging activity of $A$. dorsata, A. florea and all other dipteran pollinators peaked between 10:00 AM.-12:00 PM, however, peak activity for $A$. dorsata and $A$. cerana was observed between 12:002:00 PM.

\section{Effect of two pollination methods on the onions seed yield:}

During the two seasons of 2015/2016 and 2016/2017 the caged plants (caged throughout the flowering season/no insect visitation) produced an average of (45.40 and 47.60 seeds/ 20 umbels) respectively, whereas open-pollinated plants produced (711.60 and 721.10 seeds/ 20 umbels) respectively (fig, 6)

According to Devi et al. (2015) compared between different modes of pollination on yield parameters of $A$. cepa and found that open-pollination + handpollination resulted maximum seed yield (1430 seeds / umbel) followed by openpollination (1247 seeds / umbel), bee-pollination (1217 seeds/ umbel) and handpollination (959.6 seeds/ umbel). The least number of seed set (90 seeds / umbel) was observed with caged umbels. Bezabih and Gebretsadikan (2014) stated that open pollination treatments especially with honey bees increased onion seed quality and quantity. Munawar et al. (2011) found that onion seed setting is dependent on insect pollination. Walker et al. (2011) found that self-pollination umbels set significantly fewer seeds (average 8 seeds/umbel, $n=10$ ) than hand-pollinated umbels (average 146 seeds/umbel) and free pollination umbels (average 481 seeds/umbel). Sajjad et al. (2008) found that caged plant produced (130 seeds/ umbel) whereas open pollinated plants produced 932 seeds/ umbel). Wilkaniec et al. (2004) compared between three method of onion pollination and found that the free pollination was the highest yield (13.99 g / 5 umbels) followed by the umbels covered with the solitary bee Osmia rufa (13.84 g / 5 umbels) and the least was at the self-pollination ( $1.52 \mathrm{~g}$ / 5 umbels).

El-Zakardy et al. (1999) found that the two years mean number of setting capsules for insect excluded umbels (75.69/ umbel) compared with (270.89/ umbel) for open pollinated umbels. 


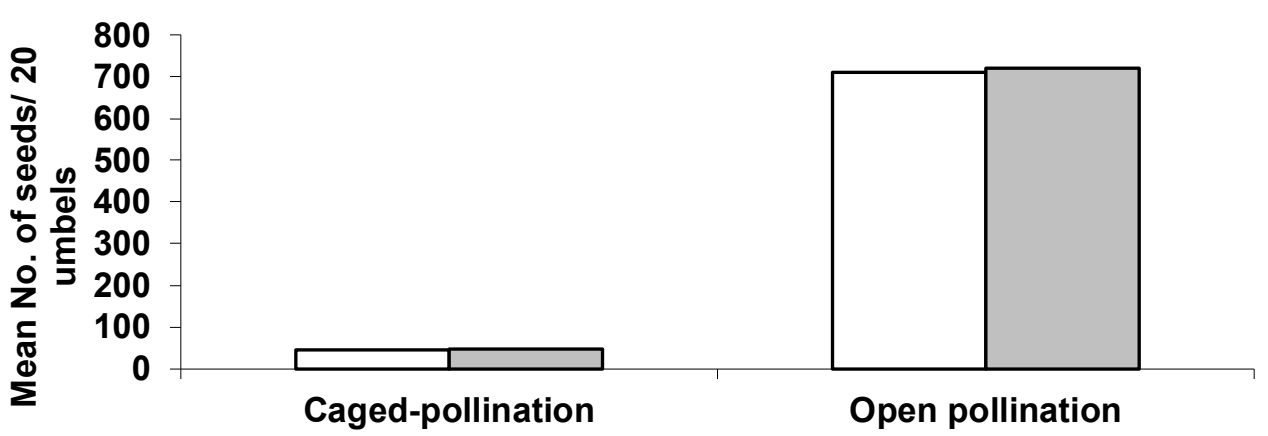

Fig 6. Seeds number of onions at free and self pollination during 2015/2016 and 2016/2017 seasons.

\section{REFERENCES}

1. Bezabih, G. and K. Gebretsadikan 2014. Managed honeybees (Apis mellifera L.) increase onions (Alliun cepa) seed yield and quality. Livestock Res. Rural Develop.;. 26(1).

2. Chandel, R. S. ; R. K. Thakur ; N. R. Bhardwaj and N. Pathania 2004. Onion seed crop pollination: a missing dimension in mountain horticulture. Acta Horticulturae, 631: 79-86.

3. Devi, S. ; R. Gulati ; K. Tehri and A. Poonia 2015. Effect of different modes of pollination on yield parameters of Allium cepa L. J. Entomol. Res., 39(2):111-117.

4. El-Zakardy, K. A. H. ; A. Khater, and E. E. Tharwat 1999. Effect of honey bees and other insect pollinators on the yield of onion seeds. Egyptian j. appl. Sci. 14(12): 675-684

5. Kalmath, B. S. and H. N. Sattigi 2005. Pollinator fauna and foraging behaviour of honey bees in onion ecosystem. (Advances in Pollen Spore Research Vol. XXII). Changing trends in pollen spore research; 25-28.

6. Lesley, C. and D. C. Ockendon 1978. Protandry and sequence of flower opening in the onion (Allium cepa L.). New phytologist, 81: 419-428.

7. Mayer, D.F and Lunden, J.D. 2001. Honey bee management and wild bees for pollination of hybrid onion seed. Acta Horticulturae., 561: 275-278.

8. Munawar, M. S.; Raja S. ; Niaz S. and G. Sarwar 2011. Comparative performance of honeybees (Apis mellifera L.) and blow flies (Phormia terronovae) in onion (Allium cepa L.) seed setting. J. Agric. Res. (Lahore); 49(1):49-56. 
9. Mupade, R. V.; Kulkarni, S. N. and G. S. Kamte 2009. Abundance of different insect pollinators in onion. Indian J. Plant Protec.; 37(1/2):83-86.

10. Partap, U. and L. R. Verma 1994. Pollination of radish by Apis cerana. J. Apic. Res., 33: 237-241.

11. Priti 1998. Abundance and pollination efficiency of insect visitors of onion bloom. Indian Bee J., 60: 75-78.

12. Saeed S.; Sajjad A.; OhSeok K. and K. Y. Jung 2008. Fidelity of Hymenoptera and Diptera pollinators in onion (Allium cepa L.) pollination. Entomol. Res.; 38(4):276-280.

13. Sajjad, A.; Saeed, S. and A. Masood 2008. Pollinator community of onion (Allium cepa L.) and its role in crop reproductive success. Pakistan J. Zool.,40: 451-456.

14. Snedecor, G. W. 1956. Statistical methods. Lowa State Collage Press, Ames, Iowa, U.S.A.

15. Walker, M. K.; Howlett, B. G.; Wallace, A. R.; Mccallum, J. A. and D. A. J. Teulon 2011. The diversity and abundance of small arthropods in onion, Allium cepa, seed crops, and their potential role in pollination. J. Insect Sci. (Madison); 11:Article 98.

16. Witter, S. and B. Blochtein 2003. Effect of pollination by bees and other insects on the production of onion seeds. Pesquisa Agrop. Brasileira, 38(12): 1399-1407.

17. Wilkaniec, Z.; Giejdasz, K. and G. Proszynski 2004. Effect of pollination on onion seeds under isolation by the mason bee (Osmia rufa L.) (Apoidea, Megachilidae) on the setting and quality of obtained seeds. J. Apic. Sci., 48:35-41. 


\section{نشاط الملقحات على أزهار البصل وتأثيرها

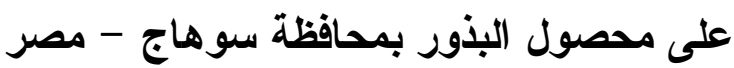

أحمد رمضان أحمد مزيد' و رفعت علام مرعى '

$$
\begin{aligned}
& 1 \text { - قسم بحوث النحل- معهُ بحوث وقاية النباتات- مركز البحوث الزر اعبة- مصر } \\
& \text { r- قسم بحوث البصل- معهد بحوث المحاصيل الحقلية مركز البحوث الزراعية- مصر }
\end{aligned}
$$

أجريت هذه الدراسة بمحطة بحوث جزيرة شندويل بسوهاج خلال موسمي زر اعة البصـلـ

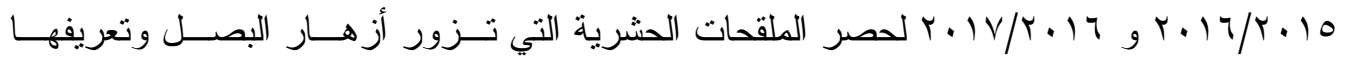



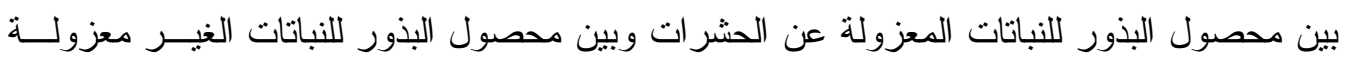

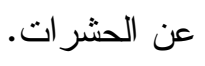

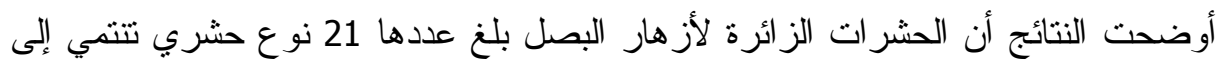

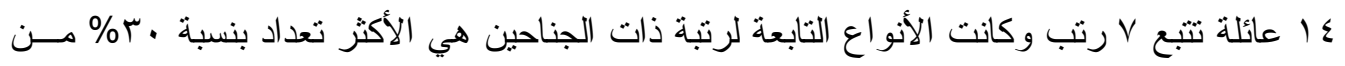

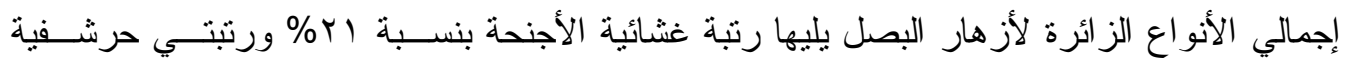

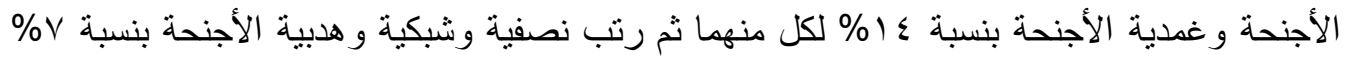
لكل منها.

وكان من أهم الأنو اع التي تتو اجد بشكل يومي على أزهار البصل هي نحل العسل و الذبابـــة

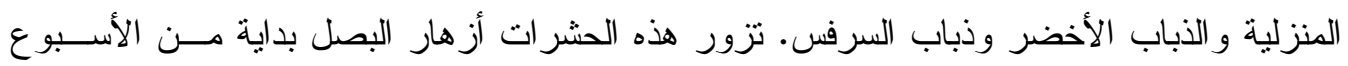
الأخير من شهر مارس إلى الأسبوع الأخير من شهر ابريل. الابل.

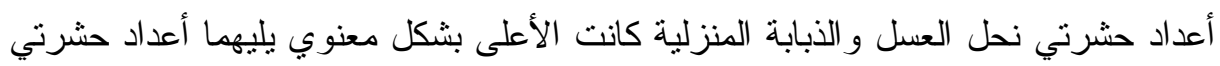

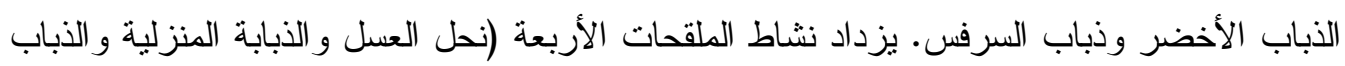

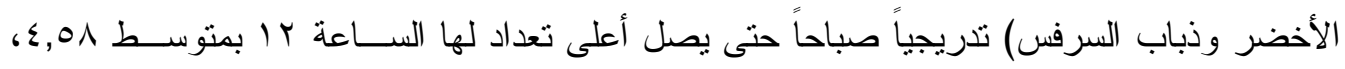

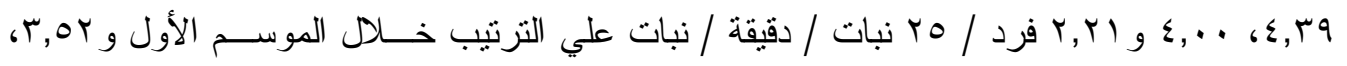

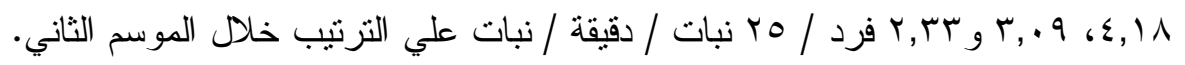

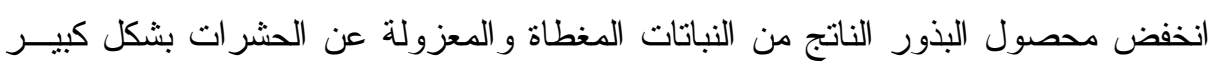

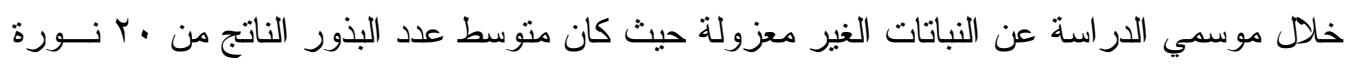




